\title{
Functional Boundaries as a Tacit Knowledge Sharing Factor and Its Effect on Public Sector Performance in Kenya
}

\author{
Susan Njeri Wamitu \\ Department of Business, School of Business and Economics, Kenya Methodist University, Nyeri Campus, \\ Nyeri, Kenya \\ Email: susanwamitu.sw@gmail.com
}

Received 4 March 2016; accepted 16 April 2016; published 19 April 2016

Copyright (c) 2016 by author and Scientific Research Publishing Inc.

This work is licensed under the Creative Commons Attribution International License (CC BY). http://creativecommons.org/licenses/by/4.0/

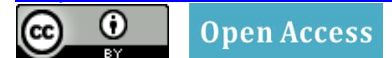

\section{Abstract}

Knowledge is a crucial component in the growth of any organization and it forms a significant fraction of all the resources required for organizational growth. Out of the renowned factors of production namely land, labor, capital, entrepreneur and management, three out of the five factors $(60 \%)$ are human factors (resource) which are actually the main drivers of knowledge management and tacit knowledge sharing. The world revolution has seen economies come from reliance on land ownership (the agricultural age), where the backbone of the economy is purely agriculture, through to the industrial age (reliance on industrialization) and now is the knowledge focus (reliance on knowledge gathering, acquisition and storage as a competitive advantage) which is the third wave of human socio-economic development. In a knowledge society, the basic economic resource is no longer capital, or natural resources or even labour, but knowledge. Knowledge is now recognized as a resource that is at par with other economic resources. It is noted that in the knowledge age, $2 \%$ of the working population will work on the land (agriculture), $10 \%$ will work in the industry (industrialization) and the rest will be in knowledge (tacit). In the Kenyan civil service, there seems to be ignorance in the amount of knowledge that flows through the Kenyan civil service every day. Chief among the reasons for this scenario is strong hierarchical (functional boundaries or strict demarcations), and bureaucracies that impede generation, distribution and sharing of knowledge and information. The performance of the Kenya public sector had failed to meet the stipulated targets as was indicated by the performance of the economic, social and other sectors in the year 2012 and 2013. In addition, empirical evidence reveals that there is a lacuna in the studies associated with tacit knowledge sharing and performance of the public sector in Kenya. The study therefore focuses on the influence of functional boundaries as a factor of tacit knowledge sharing and how they affect public sector performance in Kenya.

\section{Keywords}

Tacit Knowledge, Functional Boundaries, Competitive Advantage, Bureaucracy, Learning 


\section{Organization}

\section{Introduction}

Knowledge management (KM) is the new base of development for many economies today on the basis that it gives indisputable competitive advantage compared to other organizational resources. Knowledge, according to [1], refers to the process of capturing, developing, sharing and effectively using organizational knowledge. It is a theoretical or practical understanding of a subject which can be implicit or explicit or formal or systematic. It is the familiarity, awareness or understanding of facts, information, descriptions or skills acquired through experience or education. [2] discusses three definitions of knowledge: knowledge as nothing but perception, knowledge as true judgment, and finally knowledge as true judgment with an account. In the three definitions, the truth concept is emphasized.

\section{Overview of Knowledge Management}

\subsection{Global Perspective of Knowledge Management}

Knowledge management is as old as mankind. Its eminent debut though, can be traced in the late forties, during the Second World War, when it was noted that upon successive building of fighter planes, fewer defects were reported and this was associated with knowledge sharing. The early industrial age saw the ancient man make improvements on the survival tools which improved in quality as he made one tool after the other, each time realizing fewer defects because of perfection derived from experience. Upon such understanding, man decided to start saving the experience gained in forms that can be retrieved if need arises. This brought about the concept of learning that encouraged producers of goods to engage in quality mass production that came to warrant exchange of products in form of barter trade [3].

Several notable gurus are associated with the field of knowledge management, chief among them being Drucker [4] [5], and [6], who emphasized on the importance of knowledge as a crucial component in organizational learning. It plays an important role in ensuring that knowledge is not availed for the sake of it, but for enhancement of invention and creativity.

\subsection{Knowledge Management Initiatives in Africa}

Africa lags behind as far as knowledge management initiatives are concerned. An empirical study conducted in Malaysia by Syed-Ikhsan and Rowland [7], which investigated and examined the availability of KM strategy in the ministry of entrepreneurs and development of Malaysia and whose concerns were perceptions of KM benefits, problems, responsibilities and technology involved in managing knowledge, revealed that the ministry did not have KM strategies required to harness the benefits of knowledge even though knowledge was embedded in the ministry's procedures and policies and therefore available. Many workers felt that the ministry was responsible for managing knowledge and therefore made little attempt to go out of their way to benefit from the available knowledge.

Knowledge sharing has been defined differently in literature. [8] defines knowledge sharing as the action in which employees diffuse relevant information to others across the organization. For purposes of this study, knowledge sharing is defined as the willful application of one's ideas, insights, solutions, experiences (i.e. knowledge) to another individual either via an intermediary, such as a computer-based system, or directly [9]. According to [10], to activate knowledge movement directly across individuals and indirectly through a repository, it is important to involve individuals in knowledge sharing activities since tacit knowledge is a component of knowledge that is embedded in people's mind and which is externalized through sharing with others.

\subsection{Knowledge Management in Kenya}

Kenya has 83 registered non-profit organizations and 277 profit-making organizations which in one way or another generate knowledge but whose sharing is not ascertained. Kenya as a case in point has a civil service which keeps reinventing the wheel by doing things the same way such that if there is a mistake in the way things 
are done, the same mistake is repeated over and over again [11]. Reinventing the wheel is very costly because it is a reproduction of what others have already produced and therefore does not give the coveted competitive advantage. According to [11], Kenya exhibits similar traits with other sub-Saharan countries since she has not productively integrated KM into its government agenda.

\subsection{Tacit Knowledge Sharing Initiatives in the Kenya Civil Service}

The Kenyan public service goes by many similar names like the public sector, public service and public administration. Those working in the departments in this sector referred to as public servants or civil servants and whose responsibility is to articulate public policies and implement government strategies. These departments provide essential public utilities like education, agriculture, planning defense and health. Tacit knowledge is not well understood in the Kenyan civil service and also not embraced by many because of its abstract and intangible nature which makes people pay more attention to explicit knowledge than tacit knowledge. The Kenya civil service consistently loses experienced workers when they attain the age of 55 years and recently 60 years due to retirement. Other reasons for people leaving the service are transfers, dismissals, transfers and natural attrition. This leaves a lacuna of knowledge which in most cases is filled through explicit knowledge by those who remain [12]. Polanyi [13] advocates for harnessing of that crucial knowledge which is embedded in people’s mind and is difficult to express.

The Kenyan civil service is characterized by rigid bureaucracy and hierarchical chains that dictate the organizational structure and modes of operation [14]. This hierarchy has inflexible norms, policies, and rules which must be adhered to and only adjustable if orders come from above [15] Bureaucracies are a precursor to a culture of mistrust and impersonal interactions which inhibit tacit knowledge sharing. Comparing the Kenyan public sector with other economies bring out an interesting contrast. [16] observed that successful companies like Yahoo, Google and Intel companies rely heavily on tacit knowledge as a major asset for competitive advantage and therefore keep on generating intellectual skills which they continuously encourage members to share. It is no wonder then that they have led the world in terms of inventions and innovations.

\subsection{Functional Boundaries and Public Sector Performance}

Tacit knowledge sharing is made possible through joint activities such as being together and spending time and living in the same environment. This is regarded as the socialization stage of knowledge conversion [17]. This stage relies heavily on the quality of conversations both formally and informally [18]. The Kenyan civil service is characterized by rigid bureaucracy and extremely formal scalar chain that acts as a limitation to knowledge sharing. These are coupled with strong hierarchical chains and departmentation that demarcates areas of interactions that members may not traverse. Several researchers have undertaken studies examining the relationship between functional boundaries as a factor of tacit knowledge sharing and connected it to public sector performance. One such study is by [19], who found out that both tacit and explicit knowledge are easier to transfer over strong ties which are prevalent in team environment and which is influenced by functional boundaries. [20] measured the strength by asking respondents about relationship closeness and frequency of communication with each contact. In their study, [19] endeavored to establish knowledge sharing as very high by bringing out the issue of duration of interactions and observed that relationships became very tight in long hours of spending time together. Spending of time together is enhanced through boundary less organizational structure. The two scholars brought out the fact that the relationships must be developed over a number of years to develop trust and that the individuals must work very closely and have very strong bonds. This is made possible when there are lose or no boundaries between departments.

[21] observed in their study that where knowledge sharing is high, it is difficult to draw a line in the lives of the unit of the organization. It shows collaboration of people from different units which are beneficial if not crucial to the success of the organization. Members are simultaneously involved in more than one production unit at a time and this influences knowledge flow. These ties are very strong and enriching and contribute to organizational knowledge sharing.

[22] proposed the concept of community story telling where a community undertakes work and writes down their knowhow. [23] in their article on motivation and barriers to participation in virtual knowledge sharing communities of practice, confirm that tacit knowledge is embedded in organizational stories and delivered by organizational members through unhindered and unlimited interactions. However, they observe that apart from 
interactions that are enabled through open and direct interactions, three other key issues may hinder knowledge sharing: other people (feelings), the trait of tacit knowledge and participant's attitude to interactions.

A learning organization refers to a company that facilitates learning of its members and continually transforms itself. Learning organization concept was coined by [5] and encourages organizations to be more interconnected and become like communities that employees can feel commitment to. He notes that tacit knowledge needs to be consciously digested from members and that individual's tacit knowledge cannot be transferred into organizational knowledge without individual's acceptance and reflection. Influence of nature of functional boundaries was measured using the following indicators: nature of office plan which is assumed to be open or closed offices. Offices will be regarded as open plan if they are open halls without demarcations where employees move and interact freely without inhibitions or halfway open with half glass on the upper side. Closed plan offices are those that are completely enclosed and therefore and communication and interaction are only possible if one accesses the office through the door. Departmentation was another indicator of functional boundaries and which refers to division of work along areas of specialization and separates work assignments according to units of operations. It creates cohesion amongst departmental members but may segregate others. The indicator can enhance or inhibit tacit knowledge sharing which relies heavily on the degree of interactions and trust between departmental members.

Scalar chain refers to the pattern of authority usually occasioned by organizational structure. It is a product of centralized or decentralized authority. The more centralized authority is, the less the sharing and vice versa. The last indicator was knowledge sharing between seniors and juniors. The seniors are expected to be more experienced than the junior and therefore the more they share, the more performance of the public sector increases.

\subsection{Importance of Tacit Knowledge Sharing}

Tacit knowledge is a rich area in knowledge management whose concern is how the unwritten, unspoken and hidden store of knowledge owned by individuals, and which is derived from emotions, experiences, insights, intuitions, observations and exposure, can be shared. The main drivers of this rich area of knowledge management are partnering, close associations with people, shared activities, common interests, interactions and communication [10]. It is regarded as the hidden iceberg that makes generation of explicit knowledge possible and is also seen as a force behind many innovative ventures experienced in knowledge rich economies. Many experts have written on knowledge management but little is recorded on tacit knowledge, the probable reason being that it is found difficult to separate tacit knowledge from knowledge management or better still to distinguish or draw a line between tacit and explicit knowledge. This study may not be able to segregate tacit knowledge from the other constituents of knowledge management since tacit knowledge sharing is only one of the various components between knowledge creation and knowledge use and that they all play complementary role. It is also impractical to isolate tacit knowledge sharing from knowledge management since shedding light on one of the components means also viewing the others.

\subsection{Isolating Knowledge Management and Kenya Public Sector Performance}

Over the years, society has transformed from being agrarian to industrial and finally to emerging knowledge economies. According to a study by [24], this metastasis presents challenges to the government and also opportunities to tap from the wealth of knowledge that is available. According to [25], the key factors to these opportunities are information and knowledge which must be tapped and generated from the societies. This means that the role of knowledge in contributing to new ideas, inventions and innovations cannot be underestimated.

Kenya and other sub-Saharan countries have failed to integrate KM in government agencies; the main reason being that knowledge has not been leveraged effectively in the public sector [11]. Kenya lags behind in application of ICT and this limits the benefits it can reap from knowledge and the level of efficiency that accrues to such adoptions. According to the same study by [11] entitled enhancing government performance, effectiveness and capacity to deliver basic government services in sub-Saharan Africa through KM, it came out clearly that Kenya is not very well prepared for a knowledge economy. This is according to the World Bank's assessment on Kenya's readiness to become a knowledge economy (2004-2005) and the most recent (2007) which was rated at $1-10$.

From what is portrayed in Table 1 [26], it is noted that from the expected averages of knowledge economy growth $(1-10)$, Kenya is performing dismally and that in the crucial areas of education and innovation, the 
Table 1. Kenya’s knowledge economy readiness (most recent).

\begin{tabular}{ccc}
\hline Index & Kenya's (2004-2005) & Kenya's (most recent) \\
\hline Knowledge economy Index & 2.39 & 2.62 \\
Knowledge index (Av of 3 - 6) & 2.31 & 2.76 \\
Economic incentive and institutional regime (Av. of 4 - 6) & 2.63 & 2.21 \\
Education & 1.97 & 1.83 \\
Innovation & 4.11 & 4.18 \\
ICT & 0.85 & 2.28 \\
\hline
\end{tabular}

Source: SA Jnl Libs \& Info Sci 2009, 75(1) [26].

performance is even going down though there is hope that this might improve because ICT connectivity is improving. One of the major contributors to organizational performance is enterprise resource planning which is espoused in the next section. The World Bank's assessment for Kenya's preparedness for a knowledge economy reveals that Kenya is far from being ready for a knowledge economy. The study is informed by one crucial theory.

\section{Guiding Theory}

\section{Knowledge Economy Theory}

Knowledge economy theory was penned by [27] and is concerned with the production and distribution of knowledge as commodity function consumption within the organization's value chain. The concept of knowledge results from the recognition of the role of knowledge and technology in economic growth. Knowledge as embedded in human beings is considered as human capital which is central to economic development. Knowledge in this theory is considered as part of the most important assets in an organization, is non-imitable and in most cases, is a resource that defies the vagaries of time. The theory uses capital assets which are firm-specific resources and are indispensable in a firm's value chain [28]. Their views, point to the role played by knowledge as it interplays with other resources to create value that contributes to organizational performance.

The knowledge assets according to the theory acts as inputs that after processes and procedures are performed on them, the results are increased productivity. [29] notes that knowledge economy theory involves organizational processes and unconscious cultural knowledge that blends together to add value to the whole value chain of resources. The theory advocates for value gained through networks out of partnering of individuals to achieve competitive concentration of resources with a view of sharing knowledge which is said to decline with network length or distance [30]. The knowledge sharing network improves on skills and competencies and gives an organization enduring knowledge advantage that lasts beyond employee turnover, death, dismissal or resignation and offers the organization minimal or inconsequential knowledge loss. The theory calls for continuous KM that is motivated by the need to diversify KM across individuals to the degree that a reasonable magnitude of employee turnover does not disrupt organizational operations [31].

The theory is acknowledged as the most strategically significant resource of a firm. Proponents argue that knowledge-based resources are usually difficult to imitate and socially complex. The theory advocates that heterogeneous knowledge bases and capabilities among firms are the major determinants of sustained competitive advantage and superior corporate performance. This knowledge is embedded and carried through multiple entities including organizational culture and identity, policies, routines, documents, systems and employees. Originating from strategic management literature, this perspective builds upon and extends the resource-based view of the firm initially promoted by [32] and later expanded by [33], [34] and [35]. Although the resource-based view of the firm recognizes the important role of knowledge in firms that achieve competitive advantage, proponents of the knowledge-based view argue that resource-based view does not go far enough. Resource-based view treats knowledge as a generic resource rather than having special characteristics. However the theory fails to recognize different types of knowledge-based capabilities like information systems that can be used to synthesize, enhance and expedite large-scale intra and inter firm management [36]. The theory can also be criticized on the basis that there is no guarantee that knowledge cannot be imitated as happens in programming and plagiarism. 


\section{Methodology}

This study adopted a descriptive research design which according to [37], is used to obtain information concerning phenomena and to describe what exists based on chosen variables. The variable under study was to establish the influence of functional boundaries as a factor of tacit knowledge sharing that consequently influences public sector performance in Kenya. The data collection instrument used in this study was a questionnaire which comprised of several questions as indicated in Appendix I.

\subsection{Target Population}

The target population consisted of all public sector workers who are in the public sector ministerial departments of the 47 counties in Kenya. Table 2 provides this data.

From Table 2 [38], there were about 645,300 public sector workers according to the year 2012 statistics but this study was interested in those in the local government (Devolved Government-37,700) and those in the central Government $(222,600)$ which in total adds up to 222,600 employees. The study was mainly centered on the 47 counties in Kenya though the complimentary influence from the national government was also taken into account.

\subsection{Sampling Procedure}

The study employed use of purposive (also called judgmental, selective or subjective sampling method) which is an appropriate non-probability sampling method if the units being investigated are based on the judgment of the researcher and focuses on particular characteristics of a population [39]. Heterogeneous/maximum variation sampling (one of the types of purposive sampling) was used. The selection of the 8 counties under study out of the 47 counties was premised on the basis of equal representation of all the diverse Kenyan regions, by basing it on the former eight provinces that were a representation of Kenyan diversity. The specific counties namely Samburu, Makueni, Kirinyaga, Nairobi, Garissa, Homa Bay, Kilifi and Bungoma were purposively selected on the basis of regional representation, whereby Samburu county was selected from the former Rift Valley Province, Kirinyaga from the former Central Province, Kilifi from the former Coast Province, Makueni from the former Eastern Province, Garissa from the former North Eastern province, Homa Bay from the former Nyanza province, Bungoma from the former Western province and Nairobi county from the former Nairobi province.

The public departments that were investigated were selected using simple random sampling where $30 \%$ of the 18 ministerial departments were picked to make a total of 6 . The 6 were purposively selected out of 12 devolved functions of the government. This is demonstrated in Table 3.

Questionnaires were used to collect data. The questionnaires were pretested by administering them to 6 county directors and 15 line staff from a different county outside those that formed the study sample. Descriptive and inferential statistics were used for data analysis. Reliability was ascertained by using Cronbach alpha statistical test. The Cronbach alpha coefficient obtained was 0.84 and this study used the cutoff point coefficient of 0.7 and above as a strong measure of reliability which agrees with [39] recommendation. The questionnaire was then adjusted on the basis of the findings of the pilot test and the final version was developed thereafter for use.

\section{Analysis and Discussion}

Eight counties formed the sample and respondents were drawn from six departments mainly agriculture, trade, education, health, planning and public works. Out of the 336 questionnaires distributed to the respondents targeted by the study, 283 were returned giving a response rate of $84.2 \%$ of the target population. The results indicated that $12.7 \%$ of the respondents were from Makueni County, $14.5 \%$ from Kirinyaga County, $13.1 \%$ from Samburu County, 12.4\% from Nairobi County, 11.7\% come from Kilifi County, 11.7\% from Bungoma County,

Table 2. Number of employees in the public sector in the year 2012.

\begin{tabular}{ccccc}
\hline Sector & Central Government & $\begin{array}{c}\text { Teachers Service } \\
\text { Commission }\end{array}$ & $\begin{array}{c}\text { Parastatals Fully } \\
\text { Owned by the } \\
\text { Government }\end{array}$ & $\begin{array}{c}\text { Institutions Where } \\
\text { Government Owns } \\
50 \%\end{array}$ \\
\hline No. of Employees & 222,600 & 260,000 & 90,600 & 43,600 \\
\hline
\end{tabular}

Source: Economic survey, 2013 [38]. 
Table 3. Sampling frame for devolved departments.

\begin{tabular}{|c|c|c|c|c|}
\hline County & Public Departments & No. of County Directors & No. of Line Staff & Sample Size per County \\
\hline Samburu & 6 & 6 & $6 \times 6=36$ & 42 \\
\hline Makueni & 6 & 6 & $6 \times 6=36$ & 42 \\
\hline Kirinyaga & 6 & 6 & $6 \times 6=36$ & 42 \\
\hline Nairobi & 6 & 6 & $6 \times 6=36$ & 42 \\
\hline Kilifi & 6 & 6 & $6 \times 6=36$ & 42 \\
\hline Homa bay & 6 & 6 & $6 \times 6=36$ & 42 \\
\hline Bungoma & 6 & 6 & $6 \times 6=36$ & 42 \\
\hline Garissa & 6 & 6 & $6 \times 6=36$ & 42 \\
\hline TOTAL & 48 & 48 & 288 & 336 \\
\hline
\end{tabular}

Source: Author (2015).

11.0\% from Garisa County while 13.1\% from Homa Bay County. These can be termed as a good response rate. In order to test the effect that each factor of functional boundaries had on public sector performance, multi regression analysis was done. Tables 4-6 show the effect of each functional boundaries factors on public sector performance.

From the regression results in Table 4, the $\mathrm{R}$ value was 0.511 indicating that there is a positive relationship between functional boundaries factors and public sector performance. The $R$ squared $\left(R^{2}\right)$ value of 0.261 show that 26.1 percent of public sector performance is explained by functional boundaries factors. The remaining 73.9 percent is explained by other factors put in place by ministries in order to enhance their performance.

The model was significant with the $\mathrm{F}$ ratio $=19.588$ at $\mathrm{p} 0.000<0.05$. This is an indication that functional boundaries factors have a positive effect on public sector performance and the effect is significant.

The beta values show the degree to which each predictor variable affects the outcome when all other predictors are held constant. Departmentation, knowledge sharing, frequency of interaction with colleague and sharing of knowledge with seniors/juniors had the highest positive and significant effect on public sector performance at $\beta=0.677$ at $\mathrm{p}$ value $0.000<0.05, \beta=0.485$ at $\mathrm{p}$ value $0.001<0.05$ and $\beta=0.318$ at $\mathrm{p}$ value $0.028<0.05$ respectively. This means that as departmentation knowledge sharing, frequency of interaction with colleague and sharing of knowledge with Seniors/Juniors increased, public sector performance improved. Of the remaining functional boundaries factors nature of office plan had a positive but insignificant effect at $\beta=0.142$ and $\mathrm{p}$ value $0.230>0.05$. Nature of power structure in department had negative and insignificant effect on public sector performance at $\beta=-0.069$ and $\mathrm{p}$ value $0.626>0.05$. It can therefore conclude that functional boundaries factors have an effect on public sector performance but the effect may be positive or negative and further the effect may be significant or not significant.

The results of the study indicate that Functional boundaries factors have a positive relationship with public sector performance but the relationship can be positive or negative. The R2 value was 0.261 which translates to $26.1 \%$ contribution of functional boundary factors to public sector performance. The functional boundary factor with the highest influence was departmentation whose effect was positive and significant. This means that the more demarcated the departments are, the more influence they have on public sector performance. Power structure had a negative and insignificant effect on public sector performance. This concurs with a study by [19] that found out that the closer the sharers are, the more knowledge is shared and the more the influence on public sector performance. Departmentation segregates employees along the lines of functional specializations, location of the business in respect to strategic business units or along the type of customer that is served. This departmentation can hinder or encourage knowledge sharing and reduce or increase public sector performance.

From the regression results in Table 7, The $\mathrm{R}$ value was 0.448 indicating that there is a positive relationship between functional boundaries and public sector departments' performance. The $R$ squared $\left(\mathrm{R}^{2}\right)$ value of 0.201 shows that 20.1 percent of public sector departments' performance is explained by functional boundaries. The remaining 79.9 percent is explained by other factors put in place by ministries in order to enhance their performance. The model was significant with the F ratio $=70.752$ at p $0.000<0.05$. This is an indication that functional boundaries have a positive effect on public sector performance and the effect is significant. Given that the 
Table 4. Model summary for functional boundaries factors and public sector departments' performance.

\begin{tabular}{ccccc} 
Model & $\mathrm{R}$ & R Square & Adjusted R Square & Std. Error of the Estimate \\
\hline 1 & $0.511^{\mathrm{a}}$ & 0.261 & 0.248 & 1.87270 \\
\hline
\end{tabular}

Predictors: (Constant), share knowledge with Seniors/Juniors, nature of office plan facilitate interaction and sharing, frequency of interaction with colleagues in knowledge sharing forum, impact of depart mentation on knowledge sharing, nature of power structure in department.

Table 5. Functional boundaries factors and public sector performance.

\begin{tabular}{ccccccc}
\hline \multicolumn{2}{c}{ Model } & Sum of Squares & Df & Mean Square & F & Sig. \\
\hline & Regression & 343.479 & 5 & 68.696 & 19.588 & $0.000^{\mathrm{b}}$ \\
1 & Residual & 971.439 & 277 & 3.507 & & \\
& Total & 1314.919 & 282 & & & \\
\hline
\end{tabular}

${ }^{\mathrm{a}}$ Dependent Variable: Department Performance. ${ }^{\mathrm{b}}$ Predictors: (Constant), share knowledge with Seniors/Juniors, nature of office plan facilitate interaction and sharing, frequency of interaction with colleague in knowledge sharing forum, impact of departmentation on knowledge sharing, nature of power structure in department.

Table 6. Coefficients for functional boundaries factors and public sector departments' performance.

\begin{tabular}{ccccccc}
\hline & \multicolumn{3}{c}{ Unstandardized Coefficients } & $\begin{array}{c}\text { Standardized } \\
\text { Coefficients }\end{array}$ & T & Sig. \\
\cline { 2 - 5 } Model & B & Std. Error & Beta & & \\
\hline $\begin{array}{c}\text { (Constant) } \\
\text { Nature of office plan facilitate } \\
\text { interaction and sharing }\end{array}$ & -0.894 & 0.816 & & -1.096 & 0.274 \\
$\begin{array}{c}\text { Impact of departmentation on } \\
\text { knowledge sharing }\end{array}$ & 0.142 & 0.118 & 0.064 & 1.202 & 0.230 \\
$\begin{array}{c}\text { Frequency of interaction with } \\
\text { colleague in knowledge sharing forum } \\
\text { Nature of power structure in } \\
\text { department }\end{array}$ & 0.485 & 0.115 & 0.338 & 5.892 & 0.000 \\
$\quad \begin{array}{c}\text { Sharing knowledge with } \\
\text { Seniors/Juniors }\end{array}$ & 0.069 & 0.142 & -0.028 & -0.488 & 0.626 \\
\hline
\end{tabular}

${ }^{\mathrm{a}}$ Dependent Variable: Department Performance.

Table 7. Functional boundaries variable and public sector performance.

(a) Model Summary

\begin{tabular}{ccccc}
\hline Model & $\mathrm{R}$ & R Square & Adjusted R Square & Std. Error of the Estimate \\
\hline 1 & $0.448^{\mathrm{a}}$ & 0.201 & 0.198 & 1.93344 \\
\hline
\end{tabular}

${ }^{\mathrm{a}}$ Predictors: (Constant), functional boundaries.

(b) ANOVA

\begin{tabular}{cccccc}
\hline Model & Sum of Squares & df & Mean Square & F & Sig. \\
\hline Regression & 264.486 & 1 & 264.486 & 70.752 & $0.000^{\mathrm{b}}$ \\
Residual & 1050.433 & 281 & 3.738 & & \\
Total & 1314.919 & 282 & & & \\
\hline
\end{tabular}

${ }^{\mathrm{a}}$ Dependent Variable: Department Performance. ${ }^{\mathrm{b}}$ Predictors: (Constant), functional boundaries. 
(c) Coefficients

\begin{tabular}{|ccccccc}
\hline \multirow{2}{*}{ Model } & \multicolumn{3}{c}{ Unstandardized Coefficients } & $\begin{array}{c}\text { Standardized } \\
\text { Coefficients }\end{array}$ & t & Sig. \\
\cline { 3 - 5 } & B & Std. Error & Beta & & \\
\hline \multirow{2}{*}{1} & (Constant) & -0.759 & 0.717 & & -1.058 & 0.291 \\
& Functional Boundaries & 1.566 & 0.186 & 0.448 & 8.411 & 0.000 \\
\hline
\end{tabular}

${ }^{\text {a } D e p e n d e n t ~ V a r i a b l e: ~ D e p a r t m e n t ~ P e r f o r m a n c e . ~}$

p value $0.000<0.05$.

The regression results of the functional boundaries against public sector performance indicated a positive relationship between functional boundaries and public sector performance with $\mathrm{R}=0.448$ and $\mathrm{R}$ Squared 0.201 . At $95 \%$ confidence level, the $\mathrm{p}$ value was 0.000 which was less than 0.05 . The findings of the study further indicated that departmentation knowledge sharing, Frequency of interaction with colleagues and sharing of knowledge with seniors/juniors taken as factors of functional boundaries had positive and significant effect on public sector performance. Further, nature of office plan was also found to have positive effect whereas nature of power structure in department had negative effects on performance though insignificant.

[18] observed in their study that it is easy to transfer knowledge where there are strong ties between sharers. These strong ties are possible only if employees are allowed uncontrolled interactions which are closely determined by the degree of departmentation. The same observation is echoed by [20], whose findings point to making it easy and possible for knowledge sharers to interact rather than demarcating their territories and separating them. This study also concurs with an earlier study by [40] who noted that there is a relationship between workplace space and connectedness since if one sits more than fifty meters from another, there is rarely any communication. From this finding, then it is correct to say that knowledge sharing is discouraged especially when departmentation is not only functional but also locational or regional.

A repeated study by [41] also showed a decay of all communication media with distance. Allen in his recommendations advocated for physical proximity for effective and reliable communication. This agrees the common cliché that "out of sight, out of mind" since distance hinders interaction and communication. [18] noted that the individuals who work very closely have very strong bonds. When the functional boundaries variable is regressed against public sector performance, the relationship positive and significant. The results from both the variable and its factors indicate that functional boundaries have positive and significant effect on public sector performance. This means that functional boundaries should be factored in matters of tacit knowledge sharing and that the degree to which the boundaries are enhanced, the same degree to which they influence public sector performance.

\section{Conclusion}

The study findings also reveal that functional boundaries have positive relationship with public sector performance. Following this findings, this study recommends that the layout of the office plan is designed in a manner that enhances effective and reliable communication for employees working in the same department since departmentation influences knowledge sharing through either enhancing or inhibiting. Majority of the respondents indicate that the current setup is enclosed/partitioned office layout which may limit interactions and knowledge sharing. Scalar chain/power structure of departments is found to be fairly rigid, from the findings of the study that colleagues' interactions take place but not quite often. Nature of office layout is found to affect knowledge sharing to an average extent and that an open office layout may be an appropriate layout that may enhance tacit knowledge sharing. Frequency of interaction with colleagues is found to have positive relationship with public sector performance. Office layout is found to positively influence knowledge sharing with seniors and juniors. Departmentation is also found to influence tacit knowledge sharing in the public sector. In addition, the study findings also reveal that functional boundaries have positive relationship with public sector performance.

\section{Recommendations}

Following this findings, the study recommended that the layout of the office plan be designed in a manner that enhances effective and reliable communication for employees working in the same department. Departmentation 
was also found to influence knowledge sharing and public sector performance through either enhancing or inhibiting and therefore the study recommends that when forming departments, measures should be put in place to ensure they do not hinder knowledge sharing and inhibit performance. There was also rigidity in the scalar chain or power structure. The study recommends flexibility in the scalar chain to encourage adoption of a scalar chain that encourages performance improvement.

\section{Study Limitations}

There were limitations on obtaining data especially because the study covered expansive areas that were far apart since it spanned across the eight former provinces that are now regarded as regions. This was overcome by use of research assistants. The assumption made on this study was that the relationship between the data variables was linear. Given that the interactions and dependencies of these relations are causal, it could be possible that it is non-linear and, therefore, use of non-linear models could have led to different findings. Another limitation was that the results obtained may not allow generalization to other counties as it was noted that each county had its own unique characteristics. In spite of these limitations, this current study remained rigorous in its analysis and quality of reporting. It contributes to the understanding of the relationship that exists between functional boundaries as a factor of tacit knowledge sharing and public sector performance.

\section{Areas for Further Studies}

A study focusing on the private sector where knowledge sharing is paramount due to interdependency of departments and stiff business competition is proposed. Future studies may also adopt a case study research design for large and performing firms such as commercial banks and mobile network companies to establish whether functional boundaries influence corporate sector performance.

\section{References}

[1] Davenport, T.H. and Prusak, L. (1998) Working Knowledge: How Organizations Manage What They Know. Harvard Business School Press, Boston.

[2] Jacob, K. (1997) Plato Trilogy: Theaetetus, the Sophist and the Statesman. University of Chicago Press, Chicago and London, vii+200.

[3] Cortada, A.W. and Cortada, J. (2011) Knowledge Management Yearbook. Routledge 2000-2001 Ed. Amazon Books.

[4] Drucker, P. (1999) Knowledge Worker Productivity: The Biggest Challenge. California Management Review, 41, 7994.

[5] Senge, P. (1990) The Fifth Discipline: The Age and Practice of the Learning Organization. Century Business, London.

[6] Strassman, P.A. (1985) Information Payoff: The Transformation of Work in the Electronic Age. The Information Economic Press, New Canaan.

[7] Syed, I. and Rowland, F. (2004) Benchmarking Knowledge Management in a Public Organisation in Malaysia. Benchmarking: An International Journal, 11, 238-266.

[8] Bartol, K.M. and Srivastava, A. (2004) Encouraging Knowledge Sharing: The Role of Organizational Reward Systems. Journal of Leadership and Organizational Studies, 9, 64. http://dx.doi.org/10.1177/107179190200900105

[9] Turban, C., King, N. and Viehland, B. (2004) Electronic Commerce: A Managerial Perspective. Prentice Hall, Upper saddle River.

[10] Bock, G. and Kim, Y. (2002) Breaking the Myths of Rewards: An Exploratory Study of Attitudes about Knowledge Sharing. Information Resources Management Journal, 15, 14-21. http://dx.doi.org/10.4018/irmj.2002040102

[11] Ondari, O. and Minishi, M. (2007) Enhancing Governance, Performance Effectiveness and Capacity to Deliver Basic Government Services in Sub-Sahara Africa through Knowledge Management. Paper Presented at the Knowledge Management Africa (KMA) Second Biennial Conference 2007, Nairobi, South Africa, 28 January 2007, 1-15.

[12] Butler, T. (2011) Anti-Foundational Knowledge Management. In: Schwartz, D.G. and Te'eni, D., Eds., Encyclopedia of Knowledge Management, 2nd Edition, IGI Global, Hershey, 1-11. http://dx.doi.org/10.4018/978-1-59904-931-1.ch001

[13] Polanyi, M. (1969) Knowing and Being. Chicago University Press, Marjorie Grene.

[14] Clavier, C., Sénéchal, Y., Vibert, S. and Potvin, L. (1999) A Theory-Based Model of Translation Practices in Public Health Participatory Research. Sociology of Health \& Illness, 34, 791-805. 
http://dx.doi.org/10.1111/j.1467-9566.2011.01408.x

[15] Arowolo, D. (2010) The State, Bureaucracy and Corruption in Nigeria. Academic Leadership Journal, 8, 1-5.

[16] Herbert, I. (2000) Knowledge Is a Noun Learning Is a Verb. Financial Management, 78, 68-69.

[17] Nonaka, I. and Konno, N. (1998) The Concept of Building a Foundation for Knowledge Creation. California Management Review, 40, 40-54. http://dx.doi.org/10.2307/41165942

[18] Reagans, R. and McEvily, B. (2003) Network Structure and Knowledge Transfer: The Effects of Cohesion and Range. Administrative Science Quarterly, 48, 240-267. http://dx.doi.org/10.2307/3556658

[19] Hansen, M. (2002) Knowledge Networks: Explaining Effective Knowledge Sharing in Multiunit Companies. Organization Science, 13, 232-248.

[20] Cross, R. and Cummings, J. (2004) Tie and Network Correlates of Individual Performance in Knowledge-Intensive Work. Academy of Management Journal, 47, 928-937. http://dx.doi.org/10.2307/20159632

[21] Kleiner, A. and Roth, G. (1997) How to Make Experience Your Best Teacher. Harvard Business Review, 5, $172-177$.

[22] Ardichvili, A., Page, V. and Wentling, T. (2003) Motivation and Barriers to Participation in Virtual Knowledge-Sharing Communities of Practice. Journal of Knowledge Management, 7, 64-77. http://dx.doi.org/10.1108/13673270310463626

[23] O’Hare, D. (2002) Building the Knowledge Society. In: Information Society Commission, Report to Irish Government. www.comaround.com/knowledge

[24] Word Bank (2002) Constructing Knowledge Societies: New Challenges for Tertiary Education. Education Group, Human Development Network, Washington DC.

[25] Piaget, J. (1995) Piaget’s Constructivism—Emerging Perspectives on Learning, Teaching and Technology. http://epltt.coe.uga.edu/index.php?title=Piaget\%27s_Constructivism

[26] Ngulube, P., Shezi, M. and Leach, A. (2009) Exploring Network Literacy among Students of St. Joseph’s Theological Institute in South Africa. SA Jnl Libs \& Info Sci 2009, Vol. 75, South Africa, February 2009, 56-67.

[27] Nonaka, I., Toyama, R. and Byosière, P. (2001) A Theory of Organizational Knowledge Creation: Understanding the Dynamic Process of Creating Knowledge. In: Dierkes, M., A. Berthoin, A., Child, A. and Nonaka, I., Eds., Handbook of Organizational Learning and Knowledge, Oxford University Press, New York, 491-516.

[28] Boisot, M. (1998) Culture as a Knowledge Asset in Knowledge Assets Securing Competitive Advantage in the Information Economy. Oxford University, Oxford, 119-123.

[29] Inkpen, A. and Tsang, E. (2005) Social Capital Network and Knowledge Transfer. Academy of Management Review, 30, 146. http://dx.doi.org/10.5465/AMR.2005.15281445

[30] Beazley, H., Boenisch, Z. and Harden, J. (2002) Continuity Management: Preserving Corporate Knowledge and Productivity When Employees Leave. 1st Edition, John Wiley, New York.

[31] Penrose, E. (1959) The Theory of the Growth of the Firm. John Wiley, New York.

[32] Wernerfelt, B. (1984) A Resource-Based View of the Firm. Strategic Management Journal, 5, 171-180. http://dx.doi.org/10.1002/smj.4250050207

[33] Barney, J. (1991) Firm Resources and Sustained Competitive Advantage. Journal of Management, 17, 99-120. http://dx.doi.org/10.1177/014920639101700108

[34] Conner, K. (1991) A Historical Comparison of the Resource Based Theory and Five Schools of Thought with Industrial Organisation Economics: Do We Have a New Theory of the Firm? Journal of Management, 17, 121-154. http://dx.doi.org/10.1177/014920639101700109

[35] Alavi, M. and Leidner, D. (2001) Review: Knowledge Management and Knowledge Management Systems: Conceptual Foundations and Research Issues. MIS Quarterly, 25, 107-136. http://dx.doi.org/10.2307/3250961

[36] Mugenda, O. and Mugenda, A. (2003) Research Methods. Act Press, Nairobi.

[37] Kuzel, A.J. (1999) Sampling in Qualitative Inquiry. In: Crabtrree, B.F. and Miller, W.L., Eds., Doing Qualitative Research, 2nd Edition, Sage Publications, Thousand Oaks, 33-45.

[38] Kenya National Bureau of Statistics (2013) Economic Survey. KNBS, Nairobi.

[39] Nunnally, P. (1978) Psychometric Theory. McGraw Hill, New York.

[40] Lieberman, M. (2013) Social, Why Our Brains Are Wired to Connect. Oxford University Press, Sanfransisco, 411-486.

[41] Allen, T.J.G. and Henn (2006) The Organization Architecture of Innovation: Managing the Flow of Technology, Butterworth-Heinemann. 152. 


\section{Appendix I}

\section{QUESTIONNAIRE FOR PUBLIC SECTOR DEPARTMENTS SECTION A: BIODATA}

1. Please indicate the name of your county and also your department Your County:

Department/ministry:

The position you hold in your department:

2. How long have you worked in this department?

More than 15 years

Between 10 - 15 years

Between 5 - 9 years

Between 1 - 4 years

$\square$

Less than a year

3. Kindly explain briefly what you understand by the term tacit knowledge sharing.

\section{SECTION B: FUNCTIONAL BOUNDARIES}

4. State the nature of your office plan

Open plan office layout

Enclosed/partitioned office layout

Landscape office layout

Multi person office

No office (and if any, it is undefined)

5. To what extent does the nature of the office plan facilitate interactions and sharing?

To a very large extent

To an average extent

To a small extent

Has no effect

Inhibits

$\square$

$\square$

$\square$

$\square$

6. What would you say is the influence of departmentation on knowledge sharing?

Greatly promotes

Fairly promotes

Promotes

No influence

Deters

7. How often do you interact with your colleagues in a knowledge sharing forum?

Very often

Often

Fairly often

Never

Not sure

$\square$

$\square$

8. How would you describe the scalar chain or rather protocol or power structure in your department?

Very rigid

Rigid

Fairly rigid

Weak

Indefinable

9. How free are you to share knowledge with your seniors/juniors?

Very free

Free

Fairly free

Not free

Hard to tell

$$
\begin{aligned}
& \square \\
& \square \\
& \square \\
& \square \\
& \square
\end{aligned}
$$


10. Amongst other factors that contribute to public sector performance, how much does knowledge sharing contribute?

Over $90 \%$

$75-89 \%$

$\square$

$50-74 \%$

$25-49 \%$

$\square$

Below 24\%

\section{Thank You}

